\title{
Quantifying the offensive sequences that result in goals in elite futsal matches
}

\section{Hugo Sarmento, Paul Bradley, M. Teresa Anguera, Tiago Polido, Rui Resende \& Jorge Campaniço}

To cite this article: Hugo Sarmento, Paul Bradley, M. Teresa Anguera, Tiago Polido, Rui Resende \& Jorge Campaniço (2016) Quantifying the offensive sequences that result in goals in elite futsal matches, Journal of Sports Sciences, 34:7, 621-629, DOI: 10.1080/02640414.2015.1066024

To link to this article: http://dx.doi.org/10.1080/02640414.2015.1066024

曲 Published online: 17 Jul 2015.

Submit your article to this journal $\asymp$

Џ Article views: 146

Q View related articles $\sqsubset$

View Crossmark data \lceil 